\title{
Competitive Strategies in The Lodging Service Sector : Five Porter Analyses And Case Study SWOT Analysis
}

\author{
Awdita Citra Birru1*, \\ Sudarmiatin ${ }^{2}$, \\ Agus Hermawan ${ }^{3}$ \\ 1,2,3Faculty of Economics, University of Malang, Indonesia
}

\begin{tabular}{|c|c|}
\hline ARTICLE INFO & ABSTRACT \\
\hline $\begin{array}{l}\text { ISSN: 2723-1097 } \\
\text { Keywords: } \\
\text { Business } \\
\text { Management; SWOT } \\
\text { Analysis; Porter Five } \\
\text { Forces; SERVQUAL }\end{array}$ & $\begin{array}{l}\text { Booking lodging services using online applications is a strategy used by companies } \\
\text { in marketing their services. One of the lodging booking platforms is RedDoorz and } \\
\text { OYO. Along with the emergence of this technology and information, causing every } \\
\text { innkeeper to have a competitive strategy. This study aims to determine the product } \\
\text { differentiation strategy, the competitive strategy with porter's five forces analysis, } \\
\text { the company's condition using SWOT analysis, and customer satisfaction with the } \\
\text { SERVQUAL dimension in lodging services Malang. The research subjects are } \\
\text { lodging services in Malang that market their products using the RedDoorz and } \\
\text { OYO platforms. The subjects of this research include Omega Guest House, Bunga } \\
\text { Cengkeh Homestay, Aurila Homestay, and Kina Family Residence. Data were } \\
\text { analyzed descriptively qualitatively with Porter's Five Forces analysis, SWOT } \\
\text { analysis and SERVQUAL dimensions. The study results indicate that the lodging } \\
\text { service sector in Malang is almost entirely only implementing a differentiation } \\
\text { strategy based on price and service. The SWOT analysis results show the second } \\
\text { quadrant point, strategy diversification, which means this position proves that a } \\
\text { business is strong but faces big challenges during the Covid-19 pandemic. So you } \\
\text { have to prepare a business strategy that has been prepared based on the results of } \\
\text { the company's SWOT analysis. Business owners in the field of services such as } \\
\text { lodging in Malang must give full attention to customers because when the level of } \\
\text { satisfaction is high it will not rule out the possibility, the visitor will return at } \\
\text { another time, this full attention is called service quality or SERVQUAL. }\end{array}$ \\
\hline
\end{tabular}

\section{Introduction}

The lodging service sector is one aspect that has an important role in developing tourism globally, especially in Malang. Lodging services are currently growing rapidly where each must compete tightly to continue growing and developing (Suprapto, 2019). In Malang itself, tens or even hundreds of lodging services have been recorded that provide various services and complete facilities. Competition begins in various ways, both in terms of services, facilities, and even offered rates. This growth condition in lodging services is evidenced by the Department of Culture and tourism data regarding the increase in the number of tourists from Malang from year to year, which shows a significant increase.

Journal of Business and Management Review Vol. 3 No. 12022 Page 001-017

DOI: $10.47153 /$ jbmr31.2732022

*Corresponding Author

Email address: awdita.citra.1804136@students.um.ac.id 
The development of booking lodging services using online applications is one of the strategies used by companies in marketing their services (Hidayatullah, 2017). In this case, the company certainly already knows its market share, where the products or services offered will be marketed. This goal can be achieved by maintaining and increasing company profits by finding customers and controlling the market. This effort is inseparable from the role of the company's marketing department in carrying out a good strategy to use the opportunities that exist in marketing. The company's position in the market can be maintained and improved (Saraswati \& Prihadini, 2020).

As we know, RedDoorz and OYO are digital technology-based companies that are now often used in booking hotel or lodging services in Malang. The emergence of this technology causes every company to have a competitive strategy in marketing its products/services. Each company knows its market position is still in demand or not in demand by tourists (Guslan et al., 2019). Even though they have partnered with RedDoorz and OYO, some problems are still faced, such as customer satisfaction. When viewed from the ratings given by consumers through their reviews, one of the problems is related to the lack of services provided by the employees and the inappropriateness of the facilities in the lodging services. One customer review stated that marketing is good, but it turns out that the place (when visited) is ordinary, people will pay according to their satisfaction. One of these disappointments needs immediate handling and clarification from the lodging provider regarding expectations in the image and the actual reality with online booking services. Therefore, it is necessary to conduct a mapping in the business model and analyse strategies that can develop a lodging service business in the future.

Improving the competitive strategy in lodging services, entrepreneurs need to implement a competitive strategy using Porter's five forces analysis, which is a strategy carried out by the company to determine the company's position and determine the right strategy, namely industry competitors, potential new entrants, threats of substitute products, threats of power (Jaya \& Yuliarmi, 2019). The bargaining power of buyers is getting bigger, and the threat of bargaining power of suppliers is getting stronger. Therefore, to survive and develop its business, a company or industry depends on the five porter forces (Marić, 2020).

Steps to find out a condition or condition of a company can be done by various analyzes, in addition to using Porter's five forces analysis, companies can use a SWOT analysis. With a SWOT analysis, lodging service business owners will find it easier to understand how to measure the organization's resources, their shortcomings, market opportunities and external threats that will occur in the future (Kusmiarti, 2020). With strategic planning and management in a business, SWOT is useful for building a more effective competitive strategy based on internal and external factors that exist in the business (Habimana et al., 2018). According to research conducted by Stefan et al. (2021) by using SWOT analysis, the company can plan strategies to get sales according 
to the planned targets and competitive strategies that will be carried out to develop their business.

Customer satisfaction, especially in the service sector, is necessary to develop and maintain their success (Liat et al., 2017). The company's superiority in the service sector depends on the uniqueness and quality shown by the service. Business owners in the field of services such as lodging in Malang must give full attention to customers, because when the level of satisfaction is high it will not rule out the possibility, the visitor will return at another time, this full attention is called service quality or SERVQUAL. The dimensions of the SERVQUAL model are divided into 5 namely Tangibles, Reliability, Responsiveness, Assurance, Empathy (Naik et al., 2010).

The purpose of this study is to analyze the competitive forces faced by the lodging service sector in Malang in running their business through the Porter Five Forces, SWOT analysis and SERVQUAL dimensions so that the results of the analysis of this study are the form of competitive forces faced by the lodging service sector and how much the threat position in the lodging service business and the competitive strategies carried out in competing with its competitors and how much the strategy has an impact on their business so that entrepreneurs can survive and survive in the lodging service business (Peng, 2021).

Therefore, companies in the lodging service sector in Malang must use a business model like this due to the lack of a competitive strategy. Given that competition with competing companies operating in the lodging service sector is very tight, companies need to develop competitive strategies in marketing their products or services. This study has limitations on research subjects. Due to the limitations of researchers digging data during the Covid-19 pandemic. It is hoped that future researchers will use this research as a reference for future research. As well as revealing research facts on other research subjects, outside of this research.

Based on previous research relevant to this study by Jaya \& Yuliarmi, (2019; Meftahudin et al., (2018); Oktamala et al., (2021); Syaiful, (2020); Yasril et al., (2019). Researchers found that with the competitive strategy applied, the conclusions drawn have not been discussed in detail. The methods used to find competitive strategies have not used the five porter, SWOT, and SERVQUAL methods simultaneously. Therefore, this research is expected to enrich knowledge in competitive strategy as an additional reference and as a consideration or input for further research on the competitive strategy through five porters, SWOT, and SERVQUAL.

\section{Literature Review}

\section{Competitive strategy}


One of the requirements for a business to win a competition in the industry is to have a competitive advantage. According to Porter, there are two basic reasons for determining the company's competitive strategy. First is the industry's attractiveness, which is indicated by the industry's profitability in the long run. Second, an analysis of the various factors that will determine the company's competitive position in the industry. Porter mentions that five competitive forces will affect the profitability of an industry, namely: potential entrants, suppliers, industry competitors, substitutes, buyers. Porter's Competitive Strategies are commonly adopted by managers in determining competitive strategies (Rahma \& Pradhanawati, 2018). The objective of a competitive strategy for a business unit in an industry is to find a position where the company can best protect itself against competitive pressures or positively influence these pressures. Since the collective strength of these pressures may also be apparent to all competitors, the key to developing a strategy is to delve beneath the surface and analyze the source of each of these forces (Lesmana, 2019).

\section{Proter Five Forces Analysis}

Porter's Five Forces model is a model created by Michael Porter, an expert and professor at Harvard University in 1979 (Dobbs, 2014), which aims to describe the framework as an analysis of the development of a business. Porter's Five Forces model is commonly used for large and small businesses and businesses already running or just starting. You can use Porter's five forces analysis (Wellner \& Lakotta, 2020). In his model, Porter divides the forces that affect markets and industries into 5 forces, namely the power of suppliers (supplier power), the power of buyers (buyer power), competition from similar companies (competitive rivalry), the threat of substitute goods (threat of substitution), the threat of new entrants (threat of new entry).

\section{SWOT analysis}

SWOT analysis is used to obtain a basic view of the strategy needed to achieve a certain goal (Vlados, 2019). In this case, an assessment of what efforts can be used as alternative solutions in strategy management and development (Namugenyi et al., 2017). According to Abdel-Basset et al. (2018) a combination of internal and external factors can determine the performance of development or organization. Both of these factors should be considered in a SWOT analysis. SWOT analysis compares external factors, opportunities and threats, with internal factors, strengths and weaknesses. The results of this analysis can provide recommendations to increase strengths and maintain opportunities, while at the same time reducing weaknesses and avoiding potential threats. SWOT analysis also serves as a useful instrument in strategic analysis activities. With this analysis, organizations can minimize weaknesses and reduce the impact of threats that must be faced (Gürel \& Tat, 2017).

\section{SERVQUAL Dimensions}


Quality is one of the keys to winning the market competition.When the company has provided quality products, it has built one of the foundations for creating customer satisfaction. Quality is a basic condition related to products, services, people, processes and the environment in meeting expectations according to existing specifications depending on the ability to produce customer satisfaction. Service quality must start from customer needs and end with customer satisfaction and positive perceptions of service quality. As the party that buys and consumes services, customers judge a company's level of service quality. Servqual is a service quality gap measurement model introduced (Raza et al., 2020). This model is known as service quality or SERVQUAL. The dimensions of the SERVQUAL model are divided into 5 namely Tangibles, Reliability, Responsiveness, Assurance, Empathy.

Tangibles are the ability of a company to show its existence to external parties. The appearance and capabilities of the company's physical facilities and infrastructure and the state of the surrounding environment are tangible evidence of the services provided by the service provider. Reliability is the company's ability to provide services as promised accurately and reliably. Responsiveness is a willingness to help and give customers fast (responsive) and appropriate assistance, with precise information delivery. Assurance is the knowledge, courtesy, and ability of company employees to foster customer trust in the company. In short, it can interpret as the knowledge and friendliness of personnel and the power of personnel to be trusted and trusted. Empathy is an effort to know and understand customer needs individually.

\section{Method}

This study uses a qualitative approach or a research procedure that uses descriptive data in written or spoken words from observable people or actors. This study uses research methods with descriptive qualitative approach type of case study. While the type of research used is field research, in this case analyzing the competitive strategy of RedDoorz and OYO in the lodging service sector in Malang City. The object in this study is the lodging service in Malang City using a business model to market its products or known as online-based applications, namely RedDoorz and OYO. The research locations include Omega Guest House, Bunga Cengkeh Homestay, Aurila Homestay, and Kina Family Residence. Researchers deliberately researched the four lodging services because, during the Covid-19 pandemic, they still received inn guests with strict health protocols. Sources of data in this study are primary data and secondary data. Informants in this study are the main informants, namely managers and employees of lodging services, while the supporting informants are consumers of lodging services. The method in this study uses porter's five forces analysis, SWOT analysis, and the SERVQUAL dimension. The validity of the data in this study used triangulation.

\section{Result and Discussion}


The lodging services sector has experienced very rapid development (Gössling et al., 2020). Especially, in big cities and cities that have tourism potential and high mobility, one of which is the city of Malang. One of the interesting developments is the development of marketing techniques or methods carried out by the lodging service sector in Malang. This causes more and more competition between businesses and the more diverse methods and techniques used to get loyal customers to their business. As we know, RedDoorz and OYO are one of the budget hotel chains in Malang known to almost all circles, from domestic tourists to foreign tourists. RedDoorz and OYO will select properties that have the potential to cooperate directly and are bound by commitments that have been set with different criteria ( Rosyadah, 2021). The online budget network helps property owners to improve the quality of their accommodation in terms of facilities and services. The minimum facilities that must be owned by each property are free wifi, mineral water, AC, clean toilet, towels, water heater, and 24-hour service, as well as a place that is always clean. Not only improve the quality of lodging, but to meet the main standards of lodging products on RedDoorz and OYO, they are also responsible for helping with online room sales.

\section{Description of Lodging Product/Service Differentiation Strategy in Malang}

Based on the study results, it was found that competition between companies was very tight in competition between companies. In competitors, several indicators were very threatening. Still, in terms of capital, these indicators had a low threat. Then, the emergence of substitute products is a big threat for lodging service business actors because consumers have begun to know the existence of daily boarding houses and apartments that are hotel replacements products. Then for the lodging service sector, the bargaining power of suppliers itself has low competition due to a large number of supplier markets so that they are not fixated on one supplier only. And lastly, the high bargaining power of consumers, namely the location and price indicators. Most consumers always want a strategic location at a low price, making it difficult for business actors in the lodging service industry. To achieve a competitive advantage, one of the strategies that can be done is a differentiation strategy by offering effectively to target customers.

The next thing that can be done is to choose the output of the interaction between consumers and companies. In this case, business actors are faced with a choice, namely the use of sophisticated or simple information systems (Salazar-Ordóñez et al., 2018). The choice is based on consideration of the company's capabilities and capabilities in the procurement of CRM (Customer Relationship Management). Of course, more capital will be needed to procure a sophisticated information system but with other alternatives. Companies can implement a CRM strategy by using ordinary telephone communication, via SMS, or supporting chat platforms such as Whatsapp, Line, and others. However, along with their joining with RedDoorz and OYO, their target reach is also wider not only from the closest consumers, therefore the location consideration 
is not only limited to the establishment of a place of business but also the location for transactions, namely through the internet network. It can be said that the research objects have "picked up the ball" by implementing strategies through the lodging service distribution channel platform (Sorin et al., 2019). The context in this case is like RedDoorz and OYO. The new hope is that by picking up the ball like this and changing the target market, there will be an increase in the number of their customers and ease of doing business with a new system that is ready to use from digital marketing service providers, namely RedDoorz and OYO.

\section{Analysis of Competitive Strategy for Lodging Services in Malang through Porter's Five Forces Analysis}

From Porter's Five Forces strategy analysis, the four research objects agree that competition is a natural thing in business. It is a reference for better thinking about developing creative ideas or changing concepts (Qehaja et al., 2017). The analysis of the five competitive forces from Porter or commonly called the Porter Five Forces is useful for lodging service business actors to understand where their business strengths lie in difficult times such as during the COVID-19 pandemic as it is today.

New Actors Threat. The threat of the new perpetrators can come from hotels or apartments in Malang. Moreover, hotels that usually provide discounts on applications such as traveloka, agoda, etc. This greatly affects the position and operation of lodging services in Oyo and Reddorz.

Supplier Position Strength. The strength of the supplier's position in the lodging service industry business in Malang itself is OYO and Reddorz, because lodging services rely on these applications to get visitors in terms of marketing.

The threat of Substitute Products. Based on the research results on the threat of substitute products in the lodging service sector in Malang are hotels, villas, and apartments. Moreover, the three places also provide more attractive facilities and prices. It's just that some places have weaknesses, namely their location is still not strategic, and they also don't have a brand with online budget hotels / VHOs. Therefore, the business of lodging services in the city of Malang must take advantage of competitors' weaknesses.

Buyer Position Strength. The strength of the buyer's position affects the course of the lodging business in Malang, especially during the Covid-19 pandemic, causing the low number of visitors to lodging services in line with government policies. Many lodging services on online platforms offer discounted prices during a pandemic like this. So the strategy undertaken by the lodging industry business players must be able to adjust the purchasing power of the people at this time. 
Competition Intensity. The intensity of competition for lodging services in the city of Malang is very tight, but business people can compete fairly and continue to upgrade the quality provided, the quality can be in terms of services and facilities provided to visitors.

\section{Strategic Analysis of Lodging Services Sector In Malang To Maintain Its Existence Through SWOT Analysis}

The COVID-19 pandemic has wreaked havoc on the economic sector, not only in large industries, but also in the lodging services sector in Indonesia, especially in the city of Malang. The current sluggish economy forces entrepreneurs to think hard about maintaining their business, one of which is a SWOT analysis (Suwanmaneepong et al., 2018). According to research by Sudarmiatin, et al. (2016) with the title Sustainable Competitive Advantage on SMEs: Bringing Local Products Toward Global Markets, good company performance results from good internal and external interactions.

Table 1 IFAS Lodging Business in Malang

\begin{tabular}{|c|c|c|c|}
\hline Internal factors & Weight & Rating & Score \\
\hline 1. Facilities that resemble hotel facilities & 0,08 & 4 & 0,32 \\
\hline 2. A building with a contemporary design & 0,08 & 3 & 0,24 \\
\hline 3. Prices that can adjust to the budget & 0,15 & 4 & 0,6 \\
\hline 4. Strategic Location & 0,12 & 3 & 0,36 \\
\hline 5. Have loyal customers & 0,09 & 3 & 0.27 \\
\hline Total & & & 1,79 \\
\hline \multicolumn{4}{|l|}{ Weakness } \\
\hline 1. Lack of employees & 0,12 & 2 & 0,24 \\
\hline $\begin{array}{l}\text { 2. Marketing that only relies on } \\
\text { RedDoorz/OYO }\end{array}$ & 0,15 & 3 & 0,45 \\
\hline 3. Inadequate facilities & 0,04 & 2 & 0,08 \\
\hline 4. Lack of differentiation & 0,12 & 3 & 0,36 \\
\hline 5. Lack of government cooperation & 0,05 & 2 & 0,1 \\
\hline Total & $\mathbf{1}$ & & 1,23 \\
\hline $\begin{array}{l}\text { Total Strengths and Weaknesses } \\
\text { X Value = (Strength Value - Weakness Val }\end{array}$ & -1, & & 3,02 \\
\hline
\end{tabular}

Source: Data processed by researchers, 2021

From Table 1, the total value of the IFAS matrix is 3.02, this illustrates a high strategic position to cover internal weaknesses and take advantage of internal strengths. The main strength of the business owner is the price that can adjust the visitor's budget with a total score of 0.6 , and the rating given is 4 . The lodging business is one of the businesses with the tight competition in Malang, with a strategic location making the 
strength of the lodging business in Malang. While its main weakness is marketing which only relies on RedDoorz and OYO with a total score of 0.15 with a rating of 3 . market its services with a wider reach, not only on RedDoorz and OYO, but other applications such as Traveloka, Pegi-Pegi, Agoda etc. From the results of IFAS, business people can take strategic steps to reach a wider range of their markets.

Table 2 EFAS Lodging Business in Malang

\begin{tabular}{|c|c|c|c|}
\hline \multicolumn{4}{|l|}{ Opportunity } \\
\hline 1. Have regular customers & 0,01 & 3 & 0,3 \\
\hline $\begin{array}{l}\text { 2. The number of new tourist attractions } \\
\text { in Malang }\end{array}$ & 0,07 & 4 & 0,28 \\
\hline 3. Good cooperation with suppliers & 0,08 & 3 & 0,24 \\
\hline $\begin{array}{l}\text { 4. There is a demand for restaurant } \\
\text { products outside hotel guests }\end{array}$ & 0,1 & 2 & 0,2 \\
\hline $\begin{array}{l}\text { 5. School holidays that increase the } \\
\text { number of visitors }\end{array}$ & 0,06 & 4 & 0,24 \\
\hline Total & & & 1,26 \\
\hline \multicolumn{4}{|l|}{ Threat } \\
\hline $\begin{array}{l}\text { 1. The number of other inns that can } \\
\text { provide discounts }\end{array}$ & 0,2 & 3 & 0,6 \\
\hline $\begin{array}{l}\text { 2. Improved facilities and quality of } \\
\text { competitors }\end{array}$ & 0,07 & 4 & 0,28 \\
\hline 3. The rapid development of technology & 0,2 & 3 & 0,6 \\
\hline $\begin{array}{l}\text { 4. The system is not good so it affects } \\
\text { income }\end{array}$ & 0,07 & 3 & 0,21 \\
\hline $\begin{array}{l}\text { 5. During the low season the number of } \\
\text { hotel guests is less than during the high } \\
\text { season }\end{array}$ & 0,05 & 3 & 0,15 \\
\hline Total & 1 & & 1,84 \\
\hline $\begin{array}{l}\text { Total Value of Opportunities and Threats } \\
\text { Y Value }=(\text { Opportunity Value-Threat Value }\end{array}$ & & & 3,1 \\
\hline
\end{tabular}

Source: Data processed by researchers, 2021

From Table 2, the total EFAS value is 3.1 to describe a high external strategy to overcome threats and take advantage of existing opportunities. From the calculation results, it can be seen that the main opportunity factor that can be utilized by lodging service owners in the city of Malang is the number of new tourist attractions in Malang. These factors are the main opportunities that business owners can take advantage of to maintain their business existence by giving ratings4. The main threat is to improve the quality of competitors with a total score of 0.28 with a rating of 4 . From the results of the preparation of IFAS and EFAS, it can be seen that the $X$ and $Y$ values ( 0.56 and - 
0.58), which later values can be used as a guide to determine the location of the lodging business quadrant in Malang. The following is a SWOT Analysis Quadrant of the lodging business in Malang based on $\mathrm{X}$ and $\mathrm{Y}$ values.

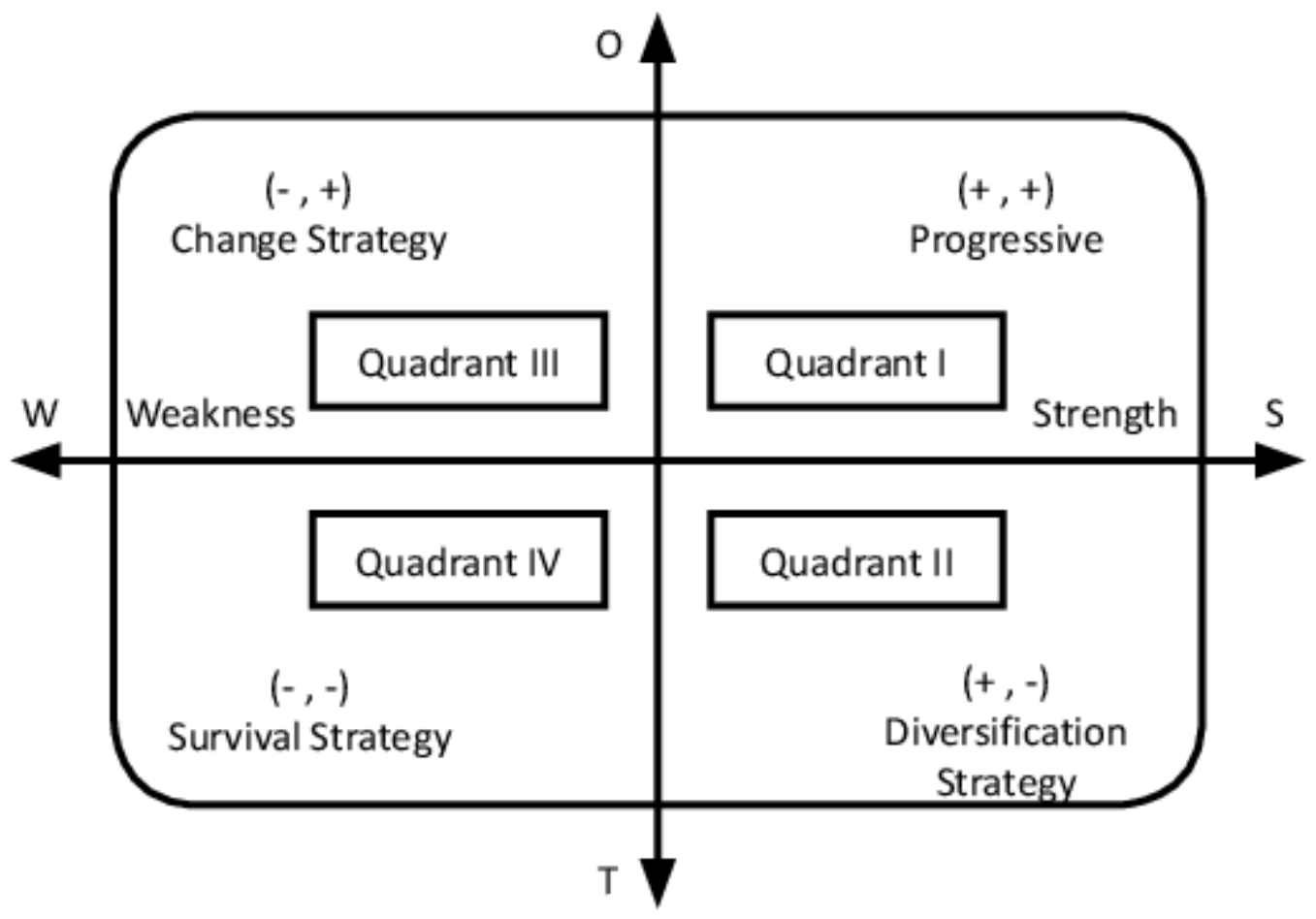

Picture 1 Quadrant SWOT

Based on the quadrant image above, the SWOT analysis on the lodging service business in Malang is in quadrant II. The results of the research on EFAS AND IFAS The values of $x(0.56$ and $y(-0.58)$ indicate that the final value results are positive and negative values, which based on the quadrant image above the value enters the second quadrant point, namely strategy diversification, which means this position proves that a strong business but faces big challenges. Businesses whose position is in quadrant II / Strategy Diversification need to re-evaluate the strategies used to reach a more serious and wider market, even though the lodging business is currently growing but can still not compete effectively. Based on the results of all the descriptions of the IFAS and EFAS evaluations that have been carried out, the initial strategy that can be designed for the development of the lodging services sector is to consistently maintain and maximize strengths and opportunities to overcome existing weaknesses and threats (Steer et al., 2019). SWOT matrix analysis needs to be done to determine what alternative strategies can support the diversification strategy and can be applied to the development of the lodging service sector in Malang. 
Table 3 Matrix SWOT Analysis

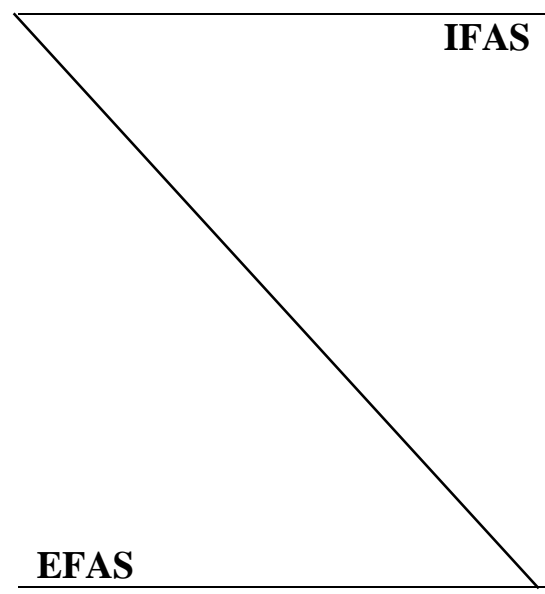

Opportunities-O

1. Have regular customers

2. There are many new tourist attractions in Malang, so there is a chance to get new consumers

3. Good cooperation from suppliers

4. There is a demand for restaurant products outside hotel guests

5. School holidays that increase the number of visitors
1. Facilities that resemble hotels include air conditioning, private bathrooms, and free Wi-Fi.

2. A building with a contemporary design so that it can attract customers

3. Prices that can adjust to the customer's budget

4. Strategic location

5. Have loyal customers

\section{Strength-Opportunity}

1. Establish good cooperation with suppliers (suppliers)

2. Expanding market share

3. Provide more competitive prices compared to competitors

4. Increase promotions to seize customers owned by competitors

5. Develop and improve the facilities or services owned at the inn

\section{Weakness-W}

1. Lack of employees so that the service is not optimal

2. Marketing that relies solely on Reddoroz/Oyo

3. Inadequate facilities

4. Lack of product/service differentiation

5. No government assistance/cooperation

\section{Weakness-Opportunity}

1. Utilizing a website in the digital marketing era as it is today

2. Continually update information about promos that give either through online or offline sites

3. Cooperating with domestic and foreign travel agencies

4. Provide swimming pool/cafe/restaurant infrastructure at the inn

5. Provide several choices/variations of promos so that they can adjust to the needs of consumers

\section{Threat-T}

\section{Strenght-Threat}

Weakness-Threat

1. The number of other depositors who can provide a discounted price

2. Improved facilities and service quality at competitor lodging

3. The rapid development of technology

4. The system is not sound so that it affects income because of the lack of continuous promotions
1. Provide full service to customers to feel safe and comfortable, especially customers of lodging services.

2. Provide attractive and competitive price offers and quality

3. They continue to innovate on the quality of products and services different from competitors

4. Always provide information
1. Creating a remarkable strategy for the distribution of promotions to consumers.

2. Cooperating with foreign travel agencies.

3. Holding CSR (Corporate Social Responsibility) events/programs so that they can improve the image of the community

4. Improving the quality of human resources and facilities that are not yet available at 


\begin{tabular}{lll}
\hline $\begin{array}{l}\text { 5. During low season } \\
\text { conditions, the number of } \\
\text { hotel guests is less than } \\
\text { during the high season }\end{array}$ & $\begin{array}{l}\text { about promos to customers } \\
\text { through social media or } \\
\text { other promotional media }\end{array}$ & the inn \\
\hline
\end{tabular}

The SWOT analysis uses data that has been obtained from the IFAS and EFAS matrices, the four main strategies suggested are S-O (Strength-Opportunities), W-O (Weakness-Opportunities), S-T (Strength-Threats) and W-T (Weakness-Threats) strategies (Satghare \& Sawant, 2018). Talking about the SO (Strength-Opportunities) strategy, 5 alternative strategies can be carried out by the lodging service sector, namely: establishing good cooperation with suppliers or suppliers, expanding market share, providing more competitive prices compared to competitors, increasing promotions so that can seize customers owned by competitors, develop and improve facilities or services owned by lodging services. As for the WO (WeaknessOpportunities) strategy, 5 alternative strategies can be done: utilizing websites in the current digital marketing era, always updating promos that will be given through online or offline sites, collaborating with bureaus. Domestic and foreign travel, providing infrastructure for lodging.

Talking about the ST (Strenght-Threats) strategy, 4 alternative strategies can be used, namely: providing maximum service to customers so that they feel safe and comfortable, especially for lodging service customers, offering attractive and competitive prices and quality, continuing to innovate towards the quality of products and services that are different from competitors, always providing information about promos to customers through social media or other promotional media. As for the WT (Weakness Threat) strategy, 4 alternatives can be used for the lodging service, namely: creating a special strategy for distributing promotions to consumers, collaborating with foreign travel agencies, holding CSR (Corporate Social Responsibility) events/programs so that can improve the image in the community, improve the quality of human resources and facilities that are not yet available at the inn.

\section{Customer Satisfaction Analysis of Lodging Services in Malang Through the SERVQUAL Dimension}

Business owners in the field of services such as lodging in Malang must give full attention to customers, because when the level of satisfaction is high it will not rule out the possibility, the visitor will return at another time, this full attention is called service quality or SERVQUAL (Ahmed et al., 2017). Researchers analyzed the four lodging services with the same steps, and the results of the SRVQUAL analysis are described as follows:

Tangibles. Based on the research results on the Tangibles factor, the clove flower inn can be said to be better, because the inn is included in the 3-star hotel category. From this, the clove flower inn has many supporting facilities that make customers feel 
satisfied, even visiting many times. In addition, the clove flower inn also provides many promos for its customers. As for Omega Guest House, Aurila Homestay, and Kina Family Residence, there are still many shortcomings in terms of facilities and services.

Reliability. The level of reliability is good, because there are rarely complaints from the end, and the rating on the application is also high. Reliability relates to staff friendliness, punctuality when checking in. Each inn must be provided with a suggestion box. If there are shortcomings or things that may not be pleasing to the consumer, they can criticize through the suggestion box or provide values and comments on applications such as OYO and RedDoorz.

Responsiveness. The response of lodging service business actors is quite good because they can respond to complaints / criticisms of their visitors.

Assurance. The employees of every lodging service in Malang are quite good at treating customers and serving every need of their visitors.

Empathy. Employees get bonuses/tips from visitors, this can be a benchmark that the services provided by the inn services are good, so visitors also give bonuses to the inn service employees as a thank you.

\section{Conclusion}

Based on the results of the analysis that has been carried out, this research has concluded that in competition between companies, competition between companies is very tight. In competitors, several indicators are very threatening, but these indicators have a low threat in terms of capital. Most consumers always want a strategic location at a low price, making it difficult for business actors in the lodging service industry.

The analysis of the five competitive forces from Porter or commonly called the Porter Five Forces is useful for lodging service business actors to understand where their business strengths. The threat of new perpetrators comes from hotels or apartments in Malang. Moreover, hotels that usually provide discounts on applications such as traveloka, agoda, etc. The strength of the supplier's position in the lodging service industry business in Malang itself is OYO and Reddorz, because lodging services rely on these applications to get visitors in terms of marketing. The threat of substitute products in the lodging service sector in Malang is hotels, villas, and apartments. The strength of the buyer's position is by providing promos as an effort to survive during the covid-19 pandemic. The intensity of competition for lodging services in Malang is very tight, but business people can compete fairly and continue to upgrade the quality provided, the quality can be in terms of services and facilities provided to visitors. 
SWOT analysis on the lodging service business in Malang is in quadrant II. The research results on EFAS and IFAS are in the second quadrant point, namely strategy diversification, which means that this position proves that a business is strong but faces big challenges. Businesses whose position is in quadrant II / Strategy Diversification need to re-evaluate the strategies used to reach a more serious and wider market, even though the lodging business is currently growing but can still not compete effectively.

The dimensions of the SERVQUAL model are divided into 5 namely Tangibles, Reliability, Responsiveness, Assurance, Empathy. Based on the research results in the Tangibles factor, the clove flower inn can be said to be better in terms of direct evidence, because the inn is included in the 3-star hotel category. As for Omega Guest House, Aurila Homestay, and Kina Family Residence, there are still many shortcomings in terms of facilities and services. The level of reliability is already good, because there are rarely complaints from the end, and the rating on the application is also high. The response of lodging service business actors is quite good because they can respond to complaints/criticisms of their visitors. In terms of Assurance, based on the results of employee research, every lodging service in Malang is quite good when viewed in terms of how to treat customers, serving every visitor's needs. Empathy includes the services provided by the inn services are good, so visitors also give bonuses to the inn's employees as a thank you.

\section{Acknowledgement}

The lodging service sector in Malang must first realize that the lodging service business is in a mature industry. These are threats and opportunities. From the conclusions above, the suggestion that can be expressed by the researcher is that the company focuses on market penetration strategies to increase company sales by intensifying existing marketing in each lodging business in several ways such as expanding distribution channels, making promos that attract consumers. Improve employees so that they can improve services more optimally. In addition, companies are advised to continuously evaluate strategies to adjust to market developments to choose the right strategy to face the existing competition. The limitations of the researcher in taking this research data include: Not discussing finance and personnel and not being able to use analytical techniques other than Porter's five forces analysis, SWOT analysis, and the SERVQUAL dimension. For further researchers, it hopes that this research can be used as a literature review material and will examine other sectors.

\section{References}

Abdel-Basset, M., Mohamed, M., \& Smarandache, F. (2018). An extension of neutrosophic AHP-SWOT analysis for strategic planning and decision-making. Symmetry, 10(4). https:/ / doi.org/10.3390/sym10040116

Ahmed, R. R., Vveinhardt, J., Štreimikienė, D., Ashraf, M., \& Channar, Z. A. (2017). 
Modified SERVQUAL model and effects of customer attitude and technology on customer satisfaction in banking industry: mediation, moderation and conditional process analysis. Journal of Business Economics and Management, 18(5), 974-1004. https:/ / doi.org/10.3846/16111699.2017.1368034

Dobbs, M. E. (2014). Guidelines for applying Porter's five forces framework: A set of industry analysis templates. Competitiveness Review, 24(1), 32-45. https:/ / doi.org/10.1108/CR-06-2013-0059

Gössling, S., Scott, D., \& Hall, C. M. (2020). Pandemics, tourism and global change: a rapid assessment of COVID-19. Journal of Sustainable Tourism, 29(1), 1-20. https:/ / doi.org/10.1080/09669582.2020.1758708

Gürel, E., \& TAT, M. (2017). SWOT Analysis: A Theoretical Review. The Journal of International Social Research, 10(15), 6-11.

Guslan, D., Hilman, T., \& Ip, S. (2019). ISSN : 2086-8561 Penentuan Digital Distribution Channel Jasa Penginapan Wisma Dalam Menunjang Kepariwisataan Kota Bandung ISSN : 2086-8561 2. MODEL PENGOLAHAN DATA. 09(2), 129-135.

Habimana, T., Mutambuka, D., \& Habinshuti, P. (2018). The Contribution of SWOT Analysis in the Competitiveness of Business Enterprises in Rwanda. Journal of Economics, Business and Management, 6(2). https:/ / doi.org/10.18178/joebm.2018.6.2.550

Hasrat, T., \& Rosyadah, K. (2021). Usability Factors as Antecedent and Consequence on Business Strategy and SERVQUAL: Nielsen \& Mack Approach. Golden Ratio of Marketing and Applied Psychology of Business, 1(2), 81-92. https://doi.org/10.52970/grmapb.v1i2.80

Hidayatullah, M. Y. (2017). Efektivitas Kegiatan Public Relations Online Melalui Website Sebagai Pendukung Strategi Pemasaran Di Hotel Bayu Hill Takengon. Ilmiah Mahasiswa FISIP Unsyiah, 2, 1-7.

Jaya, P. E. J., \& Yuliarmi, N. N. (2019). Factors Influencing Competitiveness of Small and Medium Industry of Bali: Porter'S Five Forces Analysis. Russian Journal of Agricultural and Socio-Economic Sciences, 89(5), 45-54. https:/ / doi.org/10.18551/rjoas.2019-05.06

Kusmiarti, P. (2020). Analisis Swot Pada Koperasi Karyawan Pt Bumitama Gunajaya Agro. Jurnal Ekonomi Manajemen Sistem Informasi, 1(3), 197-206. https://doi.org/10.31933/jemsi.v1i3.90

Lesmana, R. (2019). Analisis Strategi Bersaing Pt Dwi Perkasa Mobiltama Pamulang Untuk Meningkatkan Penjualan. Jimf (Jurnal Ilmiah Manajemen Forkamma), 1(4), 1-12. https:/ / doi.org/10.32493/frkm.v1i4.2554

Liat, C. B., Mansori, S., Chuan, G. C., \& Imrie, B. C. (2017). Hotel Service Recovery and Service Quality: Influences of Corporate Image and Generational Differences in the Relationship between Customer Satisfaction and Loyalty. Journal of Global Marketing, 30(1), 42-51. https:/ / doi.org/10.1080/08911762.2016.1262932

Marić, K. (2020). Analiza utjecaja pet Porterovih sila na konkurentnost hrvatskih 
izvoznih poduzeća. Obrazovanje Za Poduzetništvo - E4E, 10(1), 163-188.

https:/ / doi.org/10.38190/ope.10.1.13

Meftahudin, M., Putranto, A., \& Wijayanti, R. (2018). Penerapan Analisis SWOT dan

Five Forces Porter Sebagai Landasan untuk Merumuskan Strategi Pemasaran dalam Meningkatkan Laba Perusahaan (Studi Pada Tin Panda Collection di Kabupaten Magelang). Journal of Economic, Management, Accounting and Technology, 1(1), 22-30. https://doi.org/10.32500/jematech.v1i1.209

Naik, Krishna. N., Gantasala, S. B., \& Prabhakar, G. V. (2010). Service Quality (Servqual) and its effect on customer satisfaction in retailing. European Journal of Social Sciences, 16(2), 239-251.

Namugenyi, C., Nimmagadda, S. L., \& Reiners, T. (2017). SWOT ANALYSIS : A THEORETICAL REVIEW Design of a SWOT Analysis Model and its Evaluation in Diverse Design of a SWOT Analysis Model and its Evaluation in Diverse. Procedia Computer Science, 159(2019), 1145-1154.

Oktamala, S., Zuraidah, E., Studi, P., Infromasi, S., \& Nusamandiri, U. (2021). Metode Servqual. 8(2).

Peng, Y. (2021). TikTok's Business Model Innovation and Development - Porter's Five Forces Model, Business Model Canvas and SWOT Analysis as Tools. Proceedings of the 1st International Symposium on Innovative Management and Economics (ISIME 2021), 185(Isime), 482-489.

https:/ / doi.org/10.2991/aebmr.k.210803.066

Qehaja, A. B., Kutllovci, E., \& Pula, J. S. (2017). Strategic management tools and techniques usage: A qualitative review. Acta Universitatis Agriculturae et Silviculturae Mendelianae Brunensis, 65(2), 585-600. https:/ / doi.org/10.11118/actaun201765020585

Rahma, A. N., \& Pradhanawati, A. (2018). Strategi Bersaing Produk Ukm Lunpia dengan Menggunakan Analisis Five Forces Porter dan SWOT (Kasus pada UKM Lunpia Kings Semarang). Jurnal Ilmu Administrasi Bisnis, 7(2), 171-185.

Raza, S. A., Umer, A., Qureshi, M. A., \& Dahri, A. S. (2020). Internet banking service quality, e-customer satisfaction and loyalty: the modified e-SERVQUAL model. TQM Journal, 32(6), 1443-1466. https:/ / doi.org/10.1108/TQM-02-2020-0019

Salazar-Ordóñez, M., Rodríguez-Entrena, M., Cabrera, E. R., \& Henseler, J. (2018). Survey data on consumer behaviour in olive oil markets: The role of product knowledge and brand credence. Data in Brief, 18, 1750-1757.

https://doi.org/10.1016/j.dib.2018.04.084

Saraswati, A., \& Prihadini, D. (2020). Analisis Strategi Marketing Public Relations Dalam Meningkatkan Loyalitas Customer Sofyan Hotel (Studi Deskriptif Pada Sofyan Hotel Cut Meutia Menteng Jakarta Pusat). LUGAS Jurnal Komunikasi, 4(2), 54-60. https://doi.org/10.31334/lugas.v4i2.1219

Satghare, H., \& Sawant, M. (2018). SWOT Analysis of Marketing Strategies Applied by MTDC for Promotion of Maharashtra Tourism. Atna - Journal of Tourism Studies, 13(2), 79-95. https:/ / doi.org/10.12727/ajts.20.6 
Sorin, E., Bobo, L., \& Pinson, P. (2019). Consensus-Based Approach to Peer-to-Peer Electricity Markets with Product Differentiation. IEEE Transactions on Power Systems, 34(2), 994-1004. https:/ / doi.org/10.1109/TPWRS.2018.2872880

Steer, K., Steer, K., Garg, L., Prakash, V., \& Gupta, V. (2019). SWOT Analysis of eMarketing for e-Business. June.

Stefan, D., Vasile, V., Oltean, A., Comes, C. A., Stefan, A. B., Ciucan-Rusu, L., Bunduchi, E., Popa, M. A., \& Timus, M. (2021). Women entrepreneurship and sustainable business development: Key findings from a swot-ahp analysis. Sustainability (Switzerland), 13(9), 1-18. https:/ / doi.org/10.3390/ su13095298

Suprapto, H. (2019). Analisis Strategi Pemasaran Dalam Menghadapi Persaingan Antar Jasa Penginapan Di Kota Lamongan (Studi Pada Hotel Mahkota Lamongan). Jurnal Manajemen, 4(3), 1049. https://doi.org/10.30736/jpim.v4i3.271

Suwanmaneepong, S., Fakkhong, S., \& Kullachai, P. (2018). SWOT analysis and marketing strategies development of agricultural products for community group in Nong Chok, Bangkok, Thailand. International Journal of Agricultural Technology, 14(7), 2027-2040.

Syaiful, F. F. (2020). Penerapan Analisis Swot Terhadap Strategi Pemasaran Usaha Minuman Kamsia Boba Milik Abdullah Di Tengah Pandemi Covid-19 Di Kabupaten Bangkalan. Jurnal Edukasi Nonformal, 17, 343-359. https:/ / ummaspul.e-journal.id/JENFOL/article/view/583

Vlados, C. (2019). On a correlative and evolutionary SWOT analysis. Journal of Strategy and Management, 12(3), 347-363. https:/ / doi.org/10.1108/JSMA-022019-0026

Wellner, S., \& Lakotta, J. (2020). Porter's Five Forces in the German railway industry. Journal of Rail Transport Planning and Management, 14(xxxx), 100181. https:/ / doi.org/10.1016/j.jrtpm.2020.100181

Yasril, T., Dachriyanus, D., \& Harmawati, H. (2019). Hubungan Kualitas Pelayanan Dimensi Servqual dengan Loyalitas Pasien di Poliklinik RSUD Arosuka Tahun 2018. Jurnal Ilmiah Universitas Batanghari Jambi, 19(3), 694. https:/ / doi.org/10.33087/jiubj.v19i3.771 